\title{
Impact Of Just-In-Time, Total Quality Management And Supply Chain Management On Organizational Performance: A Review Perspective
}

\author{
Ilyas Masudin ${ }^{1 *}$, Mohammed S. Kamara ${ }^{2}$ \\ ${ }^{1}$ Industrial Engineering Dept., University of Muhammadiayah Malang \\ Jl. Raya Tlogomas 24 Malang, Indonesia \\ ${ }^{2}$ University of Sierra Leone \\ Mount Aureol, Freetown, Sierra Leon \\ *Corresponding author, e-mail: masudin@umm.ac.id
}

\begin{abstract}
The purpose of this article aims to examine literary the relationship and practices of Just-in-Time (JIT), Total Quality Management (TQM) and Supply Chain Management (SCM) on firms and their impacts on operational performance, which in turn impact organizational performance. The method used in this work is by gathering information relating to the practices of JIT, TQM, and SCM from different journals and articles based on the survey of various researchers. The source of articles used in this study is popular journal databases such as Google scholar, EBSCO Host, science direct, Emerald, Springer Link and Scopus. From the databases, 65 articles related to those three major operations management components are collected and reviewed. The results showed that JIT, TQM and SCM practices in both manufacturing and service industry individually and jointly impact organizational performance.
\end{abstract}

Keywords: Just-in-Time, total quality management, supply chain management, organizational performance

\section{Introduction}

Over the years there have been several practices and ideas attempting to improve product quality, expedite response and reduced lead time with possibly the lowest cost. Operational practices such as Total Quality Management, Just-In-Time and Supply Chain Management have been considered as an instrument to improve operational performance and most importantly organizational performance.

Just-In-Time wipe off waste through a simple production process, organizes the smooth flow of materials, reduce setup time and efficiently utilizes resources. Just-intime (JIT) practice is considered as a powerful tool to reduce waste and inefficiency, speed up the production process and delivery performance [1]. A good JIT implementation in the industry produces a high-quality product based on the customer demand [2]; minimizing levels of inventory and improve a relationship with suppliers. Total Quality Management advocates for the establishment of a joint culture which aims at continuous improvement, customer orientation, and employees' empowerment. Aligning product design with customer expectations and focusing on quality at all stages of development and production processes, are seen as drivers of improved product quality and in turn, improved business performance [3]. Supply Chain Management involves coordinating and integrating these flows both within and among suppliers with the main aim of improving material flow throughout the supply chain. Effective management of the supply chain of reduces lead times and material costs, and improves product quality and responsiveness 
This article's focus is to evaluate the correlation and role of operational practices such as Total Quality Management, Just-in-Time, and Supply Chain Management in organizational performance. In spite of the importance of this study, a thorough evaluation of the importance of operational management practice in organizational performance shows positive results.

Kaynak [4] investigated the links between the different TQM practices, attempting, in particular, to determine how they affect organizational performance on three levels: operational, marketing and financial. The results support the argument that only a few TQM practices (supplier quality management, product/service project, and process management) have a positive effect on an organization's operational performance. Also, Kannan and Tan [3] indicated that at both strategic and operational level, linkages exist among how total quality management, just-in-time and supply chain management are viewed by the organization as part of their operations strategy. Results indicate that a commitment to quality and an understanding of supply chain dynamics have the greatest effect on performance.

This study will provide an insight and better understanding of operations management discipline for the future researcher on the relationship between quality management, just-in-time and supply chain management and their impact on organization's performance. The rest of this work is organized as follow; a brief outline and description of TQM, JIT and SCM relationship and activities on operational performance, which in turn impact organization's performance. The next section will present the method results of the practice of TQM, JIT and SCM activities on organization's performance based on the research work of various scholars on the above subject. Finally, we present our conclusion on this research work.

\section{Just in Time Practices and Organization Performance}

With the adoption of JIT production, manufacturing companies have received a significant improvement in production processes [5]. According to Manoochehri [6] in his survey on a Chinese firm recorded that between 16-45\% inventories reduced and $50-80 \%$ labor productivity increased due to the application of JIT. Since time in memorial, cost reduction, and inventory, high quality and productivity have been recorded as JIT major accomplishments. Ohno [7], characterizes JIT as having the correct role at the time and in the correct amount to get together. According to Chi Anh and Matsui [8], the knowledge of producing products by their required quantity and at the exact time and eliminating wastes in operations are derived from JIT. However, through a simple production process, wastes can be eliminated by JIT production. Moreover, JIT is based on the concept of waste reduction through simple production process [9]. Simplified production process such as the elimination of excess inventories and excess large lot sizes create a needless delay in customer times cycle.

According to Flynn, et al. [10], through variance reduction and reduced network time, TQM practice improves JIT; and through problem exposure and effective feedback process improved quality performance. Also, Fullerton, et al. [11] studied 95 firms that had executed JIT and 158 firms without JIT in different US fabricating ventures. They found that organizations with a more extensive reception of the JIT approach could accomplish better financial performance. Mehra and Inman [12] suggested that JIT was a seller and a production approach " ... that endeavors to accomplish greatness in industrial processes by lessening setup times ..." using a bunch of innovation, broadly educating workers, and sound preventive support." In theory, JIT improves profitability 
due to its impact on the two interdependent components of ROA: asset turnover, which measures sales relative to investment; and returns on sales (ROS), which measures income relative to sales Kinney and Wempe [13]. JIT is expected to improve ROA in a number of ways. First, asset turnover should increase, as JIT frees up assets and capital. A smaller asset base increases ROA. Second, lower inventory levels reduce the asset base, improving asset turnover in the short term. Third, fewer buffer inventories motivate the elimination of non-value-added activities that have a negative impact on the profit margin [14]. Moreover, in the financial performance of the firm, a study by Inman, et al. [15] shows that there is a relationship between JIT-purchasing and JITproduction in the financial performance of the firm in indirect ways or as mediating variables, JIT-purchasing and JIT-production give a direct impact on agile manufacturing performance that finally affects the financial performance of a firm.

According to Flynn, et al. [10], JIT possesses unique practices and they can be divided into four categories such as Kanban, Lot size reduction practice, JIT scheduling activities and setup time reduction process. Kanban arranges the flow in order to a shop floor because kanban card must be attached to container parts, the amount of inventory on the shop floor is controlled by the number of cards allowed. Lot size reduction practice lowers inventory and raises flexibility. JIT scheduling activities comprise of both mixed model scheduling and scheduling daily production to meet demand. Setup time reduction practices aim at reducing the time required to change machine over to work on a group of different parts, which serves as an economic requirement to the use of manufacturing lots, thereby allowing a closer match between production and customer demand. Other prior studies indicate that there is a significant relationship between the operational performance of the firm and the application of JIT. It is wellexplained in the study by Inman, et al. [15] that JIT-purchasing and JIT-production have a direct positive relationship with agile manufacturing. In their model, agile manufacturing has also a positive relationship with operational performance, therefore it can be concluded that JIT in purchasing and JIT in production activities have a positive relationship to the operational performance of the firm. Following table reviews of articles dealing with the discussion of the relationship between the operations of JIT in manufacturing activities to organization performance:

Table 1 JIT practices on organization's performance

\begin{tabular}{lccc}
\hline Author & \multicolumn{3}{c}{ Organization's performance } \\
\cline { 2 - 4 } & $\begin{array}{c}\text { Financial } \\
\text { performance }\end{array}$ & $\begin{array}{c}\text { Marketing } \\
\text { performance }\end{array}$ & $\begin{array}{l}\text { Production } \\
\text { performance }\end{array}$ \\
\hline Fullerton, et al. [11] & $\sqrt{ }$ & & \\
Ahmad, et al. [16] & $\sqrt{ }$ & $\sqrt{ }$ \\
Fullerton and McWatters [17] & $\sqrt{ }$ & & \\
Droge and Germain [18] & $\sqrt{ }$ & $\sqrt{ }$ & \\
Balakrishnan, et al. [19] & $\sqrt{ }$ & $\sqrt{ }$ & \\
Inman, et al. [15] & & $\sqrt{ }$ & $\sqrt{ }$ \\
Zelbst, et al. [20] & $\sqrt{ }$ & $\sqrt{ }$ \\
Chenhall and Langfield-Smith [21] & & & $\sqrt{ }$ \\
Green Jr and Inman [22] & & & \\
Mackelprang and Nair [23] & & & \\
Cua, et al. [24] & & & \\
Bartezzaghi and Turco [25] & & & \\
\hline
\end{tabular}


Table 1 indicates that Just in Time (JIT) has been used by many manufacturers to improve organization performance in various perspectives. Instead of figures out the relationship between JIT and those three main perspectives of the company, other studies also found the relationship of JIT practices on a specific area such as productivity, quality, lead time, and customer service [26, 27]. Chang and LEE [28] used financial accounting data to determine organizational performance. In their survey conducted, they compared firms that practices JIT and those that do not. Their results indicated that JIT has less impact on organizational performance on $\$$ sales, operating profit margin and return on investment and greater on inventory turnovers ranging from raw materials to finished goods than non-JIT firms. Also, performance on quality and flexibility are greater on JIT firms.

\section{Total Quality Management Practice and organizations Performance}

In the late $1980 \mathrm{~s}$, an attempt was made to ascertain key concepts of quality management. Lately, numerous findings have examined connections between quality and performance. Anderson, et al. [29] acknowledged vital concepts of quality management such as visionary leadership, internal and external cooperation, process management, and employee fulfillment. These constructs are considered as a foundation to customer satisfaction. Wilson and Collier [30] indicated that the fundamental principle of the Malcolm Baldrige National Quality Award is that leadership facilitates quality management system, which in turn boosts business performance. Barbara et al., (1995) proposed a framework for quality management and its effects on performance and postulated that production design and statistical control/feedback directly affect quality performance and indirectly through their impacts on process flow management, which is supposed to have a direct relation to the measurement of quality performance.

TQM unique practices such as Statistical process control provides feedback, which enables operators based their actions on variability of manufacturing activities, through the use of statistical control chats; product design for quality includes improving design characteristics through design for reliability, inter-functional design efforts, inter-corporation trial run, extensive prototyping and design modification prior to release manufacturing; and customer focus serves as a tool for TQM practices assessment in achieving customer needs in organization's effectiveness, in order to develop a match between them [10].

Organizational performance and customers services are associated with joint total quality services system [31, 32]. Positive interaction exists among TQM, organizational performance, and customer service if Malcolm Baldrige National Award, TQM practice is accepted [32]. For the past three decades, TQM has been seen as a tool responsible for the maintenance and sustenance of a customer-oriented culture and making available the right product in the right place at the right time among players in the supply chain. To accomplish this goal, an approach such as quality-based culture for improving customer satisfaction, employee satisfaction and organizational performance should be established [33].

Samson and Terziovski [34] conduct a survey on the relationship between TQM practice and operational performance, they found out that leadership, management of people and customer focus are the strongest indicators of operational performance. Wilson and Collier [30] conducted a survey of 226 quality managers using Malcolm Baldrige National Award, they indicated that leadership is the most import important driver of organizational performance. It consists of information and analysis, strategic 
planning, human resources management and process management. This drive, however, results in improved financial results and customer's satisfaction. Following table shows the tabulation of study dealing with the relationship between TQM and operational performance of the organization. Sabella, et al. [35] in their survey on TQM practices on Palestinian hospitals and their connection to performance. Their result indicated that people management, process management and information and analysis are significantly connected to performance. Thus TQM practices are a valid and reliable instrument used to foretell performance. Table 2 show summaries TQM and operational organization's performance based on previous research.

Currently, the trend of TQM practice is widely discussed about its practice in small and medium enterprises (SME). The discussions of TQM adoption in SME are given pay more attention by researchers in term the relationship between its application and SME performance. Some studies indicate that there are also correlations between TQM and SME performance, for instance, Abubakar and Mahmood [36] in their research in Nigerian SME found that from 212 SMEs, the findings are suggested that total quality management is significantly associated with SME performance. Moreover, Sinha, et al. [37] investigated 120 auto component in India and provide evidence that TQM application on that SMEs has a positive impact on the performance of the firms.

Table 2 TQM and operational organization's performance

\begin{tabular}{|c|c|}
\hline $\begin{array}{c}\text { Operational } \\
\text { performance }\end{array}$ & Authors \\
\hline Customer service & $\begin{array}{l}\text { Sit, et al. [38], Ugboro and Obeng [39], Ooi, et al. [40], } \\
\text { Agus [41], Pattanayak, et al. [42], Veltmeyer, et al. [43], } \\
\text { Masudin and Kamara [44]. }\end{array}$ \\
\hline Quality performance & $\begin{array}{l}\text { Bouranta, et al. [45], Pattanayak, et al. [42], Psomas, et } \\
\text { al. [46], Parvadavardini, et al. [47]. }\end{array}$ \\
\hline Financial performance & $\begin{array}{l}\text { Hung, et al. [48], Tanninen, et al. [49], O'Neill, et al. } \\
\text { [50], Kurt and Zehir [51], Nguyen, et al. [52], Farish, et } \\
\text { al. [53], Bu, et al. [54]. }\end{array}$ \\
\hline Productivity & $\begin{array}{l}\text { Patil [55], Ismail and Rassokha [56], Sinha, et al. [37], } \\
\text { Samson [57]. }\end{array}$ \\
\hline
\end{tabular}

\section{Supply Chain Management and Organizational Performance}

As business environments become complex, in order to remain competitive, SCM provides sustainable competitive advantage the improvement of products performance and service while simultaneously reducing cost [58]. SCM scope merges all business process order than limiting to integrated logistics.

SCM key process is its purchasing function. Therefore, it serves as mediator in integrating suppliers with purchasing internal customers, who in turn provide products and services for external customers [59]. Supply chain consists of suppliers, manufacturers and customers. To attain customer satisfaction requirement, the establishment of a link between the entire production and distribution channels of products or service should be the focus of SCM [33]. Another main factor in SCM is the integration of process throughout the entire supply chain with the main focus on adding value to customers. This reflects the management of logistics or supply base. From logistics point of view, SCM is responsible for the coordination logistics operations of organizations in the value chain [60]. 
SCM practices are group of activities undertaken by a firm to accelerate effective performance. They include both downstream and upstream sides of the supply chain [61]. The implication of SCM application of SCM performance in upstream and downstream sides can be figured out in organizational innovation. A study by Chong, et al. [62], which investigated 163 Malaysian manufacturing and service firms, found that there is a strong and direct relationship of the application of SCM on organizational and innovation performance on firms. Other research by Sezhiyan, et al. [63] which surveyed Indian manufacturers found that overall firm performance is impacted by supply effort management and SCM strategy. Those two results in order to investigate the implication of SCM strategy on firm performance are undertaken in developing countries (Asia). The relevant results about the relationship between SCM strategy and firm performance are also found in previous studies which are undertaken in developed countries. For example, A study by Liao and Kuo [64] which studied in Taiwanese electronic industries indicated that found there is a relationship between SCM capability on firm performance. The latest study by Li, et al. [65] studied about SCM practice and its implication on firm's performance undertaken in US firms, shows that SCM preparedness has significant positive relationship on firm's financial performance. Kuei, et al. [33] discussed strategic supplier partnership, customer relationship, level of information sharing, quality of information sharing, and postponement elements of SCM used determine the connection between SCM practice, competitive advantage and organizational performance. Using a data collected from 196 firms, their result indicated that SCM practices lead to competitive advantage and enhance organizational performance. Instead of the positive influence of JIT, TQM and SCM practice alone on organizational performance on manufacturing and service industry, those three aspect's connection on organizational performance has been also studied. Kannan and Tan [3] focus on how TQM, JIT and SCM are related and their impact on business performance. Their results indicated that there is connection that exists among TQM, JIT and SCM, which are considered as operations strategy. Also the willingness to quality and knowledge of supply chain activities significantly affects performance.

\section{Conclusion}

This literature survey provides justification for the relationship that exists among JIT, TQM and SCM practices and how these practices improve operations performance, which in turn positively impact organizational performance in both manufacturing and service industry. The results prove that if an organization implements any of the three practices it will produce a better or greater organizational performance. It is also proven that the relationship exists among JIT, TQM and SCM is strong and that their practices jointly impact organizational performance.

\section{References}

[1] P. Danese and P. Romano, "Supply chain integration and efficiency performance: a study on the interactions between customer and supplier integration," Supply Chain Management: An International Journal, vol. 16, pp. 220-230, 2011.

[2] P. Ward and H. Zhou, "Impact of information technology integration and lean/just-in-time practices on lead-time performance," Decision Sciences, vol. 37, pp. 177-203, 2006. 
[3] V. R. Kannan and K. C. Tan, "Just in time, total quality management, and supply chain management: understanding their linkages and impact on business performance," Omega, vol. 33, pp. 153-162, 2005/04/01/ 2005.

[4] H. Kaynak, "The relationship between total quality management practices and their effects on firm performance," Journal of operations management, vol. 21, pp. 405-435, 2003.

[5] R. Hayes, "Why Japanese factories work," Beechler, S., \& Stucker, K, pp. 81-96, 1998.

[6] G. Manoochehri, "Improving productivity with the just-in-time system," journal of Systems Management, vol. 36, pp. 23-26, 1985.

[7] T. Ohno, Toyota production system: beyond large-scale production: crc Press, 1988.

[8] P. Chi Anh and Y. Matsui, "Relationship between quality management information and operational performance: International perspective," Management Research Review, vol. 34, pp. 519-540, 2011.

[9] P. Chauhan, S. Rangrej, K. Samvatsar, and J. Patel, "Feasibility Study of Waste Reduction Using JIT Concept-A Case of Forging Industry," in Proceedings of 5th National Conference on-Recent Advances in Manufacturing, 2015.

[10] B. B. Flynn, S. Sakakibara, and R. G. Schroeder, "Relationship between JIT and TQM: practices and performance," Academy of management Journal, vol. 38, pp. 1325-1360, 1995.

[11] R. R. Fullerton, C. S. McWatters, and C. Fawson, "An examination of the relationships between JIT and financial performance," Journal of Operations Management, vol. 21, pp. 383-404, 2003.

[12] S. Mehra and R. A. Inman, "Determining the critical elements of just-in-time implementation," Decision Sciences, vol. 23, pp. 160-174, 1992.

[13] M. R. Kinney and W. F. Wempe, "Further evidence on the extent and origins of JIT's profitability effects," The Accounting Review, vol. 77, pp. 203-225, 2002.

[14] M. Alles, S. M. Datar, and R. A. Lambert, "Moral hazard and management control in just-in-time settings," Journal of Accounting Research, pp. 177-204, 1995.

[15] R. A. Inman, R. S. Sale, K. W. Green, and D. Whitten, "Agile manufacturing: Relation to JIT, operational performance and firm performance," Journal of Operations Management, vol. 29, pp. 343-355, 2011/05/01/2011.

[16] A. Ahmad, S. Mehra, and M. Pletcher, "The perceived impact of JIT implementation on firms' financial/growth performance," Journal of Manufacturing Technology Management, vol. 15, pp. 118-130, 2004.

[17] R. R. Fullerton and C. S. McWatters, "The production performance benefits from JIT implementation," Journal of operations management, vol. 19, pp. 81-96, 2001.

[18] C. Droge and R. Germain, "The relationship of electronic data interchange with inventory and financial performance," Journal of Business Logistics, vol. 21, p. 209, 2000.

[19] R. Balakrishnan, T. J. Linsmeier, and M. Venkatachalam, "Financial benefits from JIT adoption: Effects of customer concentration and cost structure," Accounting Review, pp. 183-205, 1996.

[20] P. J. Zelbst, K. W. Green Jr, R. D. Abshire, and V. E. Sower, "Relationships among market orientation, JIT, TQM, and agility," Industrial Management \& Data Systems, vol. 110, pp. 637-658, 2010. 
[21] R. H. Chenhall and K. Langfield-Smith, "Multiple perspectives of performance measures," European Management Journal, vol. 25, pp. 266-282, 2007.

[22] K. W. Green Jr and R. A. Inman, "Does implementation of a JIT-with-customers strategy change an organization's structure?," Industrial Management \& Data Systems, vol. 106, pp. 1077-1094, 2006.

[23] A. W. Mackelprang and A. Nair, "Relationship between just-in-time manufacturing practices and performance: A meta-analytic investigation," Journal of Operations Management, vol. 28, pp. 283-302, 2010/07/01/2010.

[24] K. O. Cua, K. E. McKone, and R. G. Schroeder, "Relationships between implementation of TQM, JIT, and TPM and manufacturing performance," Journal of operations management, vol. 19, pp. 675-694, 2001.

[25] E. Bartezzaghi and F. Turco, "The impact of just-in-time on production system performance: an analytical framework," International Journal of Operations \& Production Management, vol. 9, pp. 40-62, 1989.

[26] J. J. Lawrence and M. P. Hottenstein, "The relationship between JIT manufacturing and performance in Mexican plants affiliated with U.S. companies," Journal of Operations Management, vol. 13, pp. 3-18, 1995/07/01/ 1995.

[27] J.-S. Yang and J. C.-H. Pan, "Just-in-time purchasing: an integrated inventory model involving deterministic variable lead time and quality improvement investment," International Journal of Production Research, vol. 42, pp. 853-863, 2004.

[28] D. Chang and S. LEE, "Impact of JIT on organizational performance of US firms," International Journal of Production Research, vol. 33, pp. 3053-3068, 1995.

[29] J. C. Anderson, M. Rungtusanatham, R. G. Schroeder, and S. Devaraj, "A path analytic model of a theory of quality management underlying the Deming management method: preliminary empirical findings," Decision sciences, vol. 26, pp. 637-658, 1995.

[30] D. D. Wilson and D. A. Collier, "An empirical investigation of the Malcolm Baldrige National Quality Award causal model," Decision sciences, vol. 31, pp. 361-383, 2000.

[31] W. W. Tornow and J. W. Wiley, "Service quality and management practices: A look at employee attitudes, customer satisfaction, and bottom-line consequences," People and Strategy, vol. 14, p. 105, 1991.

[32] S. A. Black and L. J. Porter, "Identification of the critical factors of TQM," Decision sciences, vol. 27, pp. 1-21, 1996.

[33] C.-H. Kuei, C. N. Madu, and C. Lin, "The relationship between supply chain quality management practices and organizational performance," International Journal of Quality \& Reliability Management, vol. 18, pp. 864-872, 2001.

[34] D. Samson and M. Terziovski, "The relationship between total quality management practices and operational performance," Journal of operations management, vol. 17, pp. 393-409, 1999.

[35] A. Sabella, R. Kashou, and O. Omran, "Quality management practices and their relationship to organizational performance," International Journal of Operations \& Production Management, vol. 34, pp. 1487-1505, 2014.

[36] R. A. Abubakar and R. Mahmood, "Firm resource advantage, total quality management, SME performance: Empirical evidence from Nigerian 
manufacturing firms," MAYFEB Journal of Business and Management, vol. 1, 2016.

[37] N. Sinha, A. K. Garg, and N. Dhall, "Effect of TQM principles on performance of Indian SMEs: the case of automotive supply chain," The TQM Journal, vol. 28, pp. 338-359, 2016.

[38] W.-Y. Sit, K.-B. Ooi, B. Lin, and A. Yee-Loong Chong, "TQM and customer satisfaction in Malaysia's service sector," Industrial Management \& Data Systems, vol. 109, pp. 957-975, 2009.

[39] I. O. Ugboro and K. Obeng, "Top management leadership, employee empowerment, job satisfaction, and customer satisfaction in TQM organizations: an empirical study," Journal of quality management, vol. 5, pp. 247-272, 2000.

[40] K.-B. Ooi, B. Lin, B.-I. Tan, and A. Yee-Loong Chong, "Are TQM practices supporting customer satisfaction and service quality?," Journal of Services Marketing, vol. 25, pp. 410-419, 2011.

[41] A. Agus, "TQM as a focus for improving overall service performance and customer satisfaction: An empirical study on a public service sector in Malaysia," Total Quality Management \& Business Excellence, vol. 15, pp. 615-628, 2004.

[42] D. Pattanayak, D. Pattanayak, M. Koilakuntla, M. Koilakuntla, P. Punyatoya, and P. Punyatoya, "Investigating the influence of TQM, service quality and market orientation on customer satisfaction and loyalty in the Indian banking sector," International Journal of Quality \& Reliability Management, vol. 34, pp. 362-377, 2017.

[43] J. Veltmeyer, J. Veltmeyer, S. Mohamed, and S. Mohamed, "Investigation into the hierarchical nature of TQM variables using structural modelling," International Journal of Quality \& Reliability Management, vol. 34, pp. 462-477, 2017.

[44] I. Masudin and M. S. Kamara, "Electronic Data Interchange and Demand Forecasting Implications on Supply Chain Management Collaboration: A Customer Service Perspective," 2017, vol. 18, p. 11, 2017-09-14 2017.

[45] N. Bouranta, N. Bouranta, E. L. Psomas, E. L. Psomas, A. Pantouvakis, and A. Pantouvakis, "Identifying the critical determinants of TQM and their impact on company performance: Evidence from the hotel industry of Greece," The TQM Journal, vol. 29, pp. 147-166, 2017.

[46] E. Psomas, E. Psomas, J. Antony, and J. Antony, "Total quality management elements and results in higher education institutions: The Greek case," Quality Assurance in Education, vol. 25, pp. 206-223, 2017.

[47] S. Parvadavardini, N. Vivek, and S. Devadasan, "Impact of quality management practices on quality performance and financial performance: evidence from Indian manufacturing companies," Total Quality Management \& Business Excellence, vol. 27, pp. 507-530, 2016.

[48] R. Y. Y. Hung, B. Y.-H. Lien, B. Yang, C.-M. Wu, and Y.-M. Kuo, "Impact of TQM and organizational learning on innovation performance in the high-tech industry," International business review, vol. 20, pp. 213-225, 2011.

[49] K. Tanninen, K. Puumalainen, and J. Sandström, "The power of TQM: analysis of its effects on profitability, productivity and customer satisfaction," Total Quality Management, vol. 21, pp. 171-184, 2010.

[50] P. O'Neill, A. Sohal, and C. W. Teng, "Quality management approaches and their impact on firms' financial performance-An Australian study," International Journal of Production Economics, vol. 171, pp. 381-393, 2016. 
[51] A. Kurt and C. Zehir, "The relationship between cost leadership strategy, total quality management applications and financial performance," 2016.

[52] A. D. Nguyen, C. H. Pham, and L. Pham, "Total Quality Management and Financial Performance of Construction Companies in Ha Noi," International Journal of Financial Research, vol. 7, p. 41, 2016.

[53] K. Farish, A. P. Anil, and K. Satish, "Effect of TQM Practices on Financial Performance through Innovation Performance-In Indian Manufacturing Context," 2017.

[54] X.-Z. Bu, X.-K. Feng, and C. Liu, "TQM and it's impact on financial performance of Chinese companies," in Service Systems and Service Management (ICSSSM), 2017 International Conference on, 2017, pp. 1-6.

[55] S. B. Patil, "A Theoretical Review on Statistical Process control used in TQM to improve mass productivity," International Journal of Advanced Electronics and Communication Systems, vol. 6, 2017.

[56] M. H. Ismail and Y. Rassokha, "Benefits of TQM Technologies at the Small and Medium Enterprises," 2017.

[57] K. K. Samson, "Effects of Total Quality Management (TQM) on Firm's Operational Performance (South Korea)," 2017.

[58] T. Davis, "Effective supply chain management," Sloan management review, vol. 34, p. 35, 1993.

[59] L. L. Stanley and J. D. Wisner, "Service quality along the supply chain: implications for purchasing," Journal of operations management, vol. 19, pp. 287306, 2001.

[60] K. C. Tan, V. R. Kannan, and R. B. Handfield, "Supply chain management: supplier performance and firm performance," Journal of Supply Chain Management, vol. 34, p. 2, 1998.

[61] S. Li, B. Ragu-Nathan, T. Ragu-Nathan, and S. S. Rao, "The impact of supply chain management practices on competitive advantage and organizational performance," Omega, vol. 34, pp. 107-124, 2006.

[62] A. Y. Chong, F. T. Chan, K.-B. Ooi, and J.-J. Sim, "Can Malaysian firms improve organizational/innovation performance via SCM?," Industrial Management \& Data Systems, vol. 111, pp. 410-431, 2011.

[63] D. M. Sezhiyan, T. Page, and P. Iskanius, "The impact of supply effort management, logistics capability, and supply chain management strategies on firm performance," International Journal of Electronic Transport, vol. 1, pp. 2644, 2011.

[64] S.-H. Liao and F.-I. Kuo, "The study of relationships between the collaboration for supply chain, supply chain capabilities and firm performance: A case of the Taiwan' s TFT-LCD industry," International Journal of Production Economics, vol. 156, pp. 295-304, 2014.

[65] X. Li, X. Li, Q. Wu, Q. Wu, C. W. Holsapple, C. W. Holsapple, et al., "An empirical examination of firm financial performance along dimensions of supply chain resilience," Management Research Review, vol. 40, pp. 254-269, 2017. 